\title{
Effects of site and tree size on wood density and bark properties of Lebombo ironwood (Androstachys johnsonii Prain)
}

\author{
Tarquinio Mateus Magalhães \\ Departamento de Engenharia Florestal, Universidade Eduardo Mondlane, Campus Universitário Principal, Edifício no. 1, 257 Maputo, \\ Moçambique \\ *Corresponding author: tarquinio_magalhaes@uem.mz \\ (Received for publication 16 December 2018; accepted in revised form 15 March 2021)
}

\begin{abstract}
Background: Wood and bark are important renewable natural resources. Density is an important property that is used to describe wood and bark quality for a number of end uses. However, wood and bark density, bark proportion and dimensions vary with age and site, as well as among and within trees. The aim of this study was to investigate the effect of site, diameter class, and vertical position within the stem on the density of wood and bark, bark volume, bark dry-mass and thickness of Lebombo ironwood (Androstachys johnsonii Prain).

Methods: The study was conducted on 93 Lemombo ironwood trees growing in Mozambique. Eight discs were sampled from each selected tree and diameter over and under bark was measured. Bark thickness, bark mass and bark density were determined along with the basic wood density of each disc.

Results: The overall average whole-stem properties were estimated at: $786 \mathrm{~kg} \mathrm{~m}^{-3}$ wood density, $586 \mathrm{~kg} \mathrm{~m}^{-3}$ bark density, $19 \%$ bark volume, 19\% bark dry-mass, and $9 \mathrm{~mm}$ bark thickness. Height level uniquely explained most of the variation in bark mass (97\%), bark volume (95\%) and wood density (86\%). Diameter class explained most of the variation in bark density (51\%) and bark thickness (51\%). Site only explained a small proportion of the variation in all dependent variables.

Conclusions: Overall, the patterns of variation of all wood and bark properties were highly dependent on tree diameter class and vertical position within the stem. Site differences were not a significant source of variation in the properties studied. Improved knowledge of the wood and bark properties of this species will aid its sustainable management and utilisation.
\end{abstract}

Keywords: Bark traits; Commonality analysis; Regression effect; Suppressor effect; Wood traits

\section{Introduction}

Mecrusse is a forest type in which the dominant canopy species is Androstachys johnsonii Prain, the relative cover of which varies from $80 \%$ to $100 \%$ (Magalhães 2017a). Androstachys johnsonii is known vernacularly as Lebombo ironwood or Cimbirre. The wood of $A$. johnsonii is also known as Lebombo ironwood. Lebombo ironwood is a tree species native to Madagascar and Africa, however, presently it is almost restricted to Mozambique (Cardoso 1963), where it is mainly found in the southmost part of the country, in Inhambane and Gaza province (Magalhães 2015). In Mozambique, it is classified as a first-class timber and it is lawfully harvested at $30 \mathrm{~cm} \mathrm{DBH}$. This tree species rarely exceeds $35 \mathrm{~cm}$ in diameter at breast height (DBH) (Magalhães and Seifert 2015).

Lebombo ironwood has distinct growth ring boundaries and is diffuse-porous with vessels of two distinct diameter classes (Bunster 2006; Cardoso 1963). The growth rings are wavy causing a fine streaked appearance (Bunster 2006). The fibres are very thickwalled with distinctly bordered pits common in both radial and tangential walls (Ali 2008). The heartwood is yellowish-pale brown, sometimes slightly pink (Bunster 2006). 
Because of its durability (Bunster 2006), Lebombo ironwood is used as poles and stakes by the local community (Magalhães 2017a) and in construction of houses and bridges (Cardoso 1963). Due to its favourable mechanical properties (Cardoso 1963), Lebombo ironwood is also suitable for flooring, turnery, marine uses, furniture and interiors (Bunster 2006), stairs, laths, fences, railway sleepers, bridge piers, vehicle boards and draining boards (Ali et al. 2008; Cardoso 1963). These end uses are determined by the properties of this wood, hence the relevance of studying them. In the early 1960s, Lebombo ironwood had already been reported to be almost completely restricted to Mozambique (Cardoso 1963), presumably due to overexploitation. Five decades later, there is still a lack of studies on this species in any branch of forest science, especially studies related to wood and bark properties. This emphasises the need to study the wood properties of this species.

Basic wood density (hereafter referred simply as wood density) is an important wood quality characteristic. Wood density is used to describe wood quality in construction and in the mechanical and chemical pulp industries (Repola 2006). Various solid wood utilization characteristics such us timber strength and stiffness, machinability and drying, and some manufacture and performance reconstituted products such as raw material consumption, uptake of chemicals, pulp yield, and paper properties are dependent on wood density (Kimberley et al. 2015; Tian et al. 1995).

Along with volume, wood density is a key determinant of tree biomass (Bastin et al. 2015) and thus a key variable to make estimates of carbon pools in forests, and for studying other biochemical cycles and understanding the evolution and potential future changes of the climate system. Lebombo ironwood is heavy, with a density of 754 and $880 \mathrm{~kg} / \mathrm{m}^{3}$ at 0 and $12 \%$ moisture content, respectively (Bunster 2006; Magalhães 2015). Its high density makes it attractive to the hardwood lumber industry.

Bark is also an economically important raw material. It is used in the production of cork, fibre, tannins, pallets, briquettes, insulation boards, fibreboards, hardboards, particleboards (Pásztory et al. 2016). Bark is also used in mulching and soil amendment (Pásztory et al. 2016). Specifically, due to its allelopathic effect (Magalhães 2017a; Molotja et al. 2011), the bark of Lebombo ironwood is used to sterilise the soils in rural home gardens where only adult trees are desired (i.e. to avoid weed and seed germination). This highlights the importance of quantifying the properties and quantity of bark. Except for chemical production, most of the uses of bark (e.g., production of boards) are influenced by its density.

Knowing the thickness of bark is critical to accurately estimate the relative volumes of solid wood and bark that are available (Thomas and Bennett 2014). Stem bark volume and bark dry-mass are important because bark and wood mass are separated while processing logs, and accurate determination of volume is problematic (Thomas and Bennett 2014). Wood and bark density, bark volume and mass, and bark thickness vary with age, diameter, site, tree and within tree (longitudinally and radially) (Auty et al. 2014; Cellini et al. 2012; Kimberley et al. 2015; Machado et al. 2014; Murphy \& Cown 2015; Paine et al. 2010; Quilhó \& Pereira 2001; Repola 2006; Searle \& Owen 2005; Sonmez et al. 2007). Thus, the variations of these wood and bark properties are of particular interest to the forestry sector and the related industries (e.g. construction, fuel industries, etc.).

Although considerable studies have been carried out on the extent and sources of variation in wood and bark properties of coniferous species in Europe, North America, South America and Australasia, similar studies are lacking for tropical African broad-leaved species. The current study aimed to quantify the effects of site, diameter class, relative height within the stem and their interactions on wood and bark density, bark volume, mass, and thickness of Lebombo ironwood. As these tree variables are often measured at a single specific sampling point, generally breast height (Hernández \& Genes 2016; Tian et al. 1995), whole-stem-based properties (e.g. whole-stem wood density) were compared to the equivalent breast height-based properties.

\section{Methods}

\section{Study sites}

This study was carried out in Mecrusse woodlands of the Mandlakaze $\left(24^{\circ} 04^{\prime}-25^{\circ} 02^{\prime} \mathrm{S}\right.$ and $\left.33^{\circ} 47^{\prime}-34^{\circ} 39^{\prime} \mathrm{E}\right)$, Funhalouro $\left(22^{\circ} 09^{\prime}-23^{\circ} 42^{\prime} \mathrm{S}\right.$ and $\left.33^{\circ} 40^{\prime}-34^{\circ} 29^{\prime} \mathrm{E}\right)$ and Mabote $\left(21^{\circ} 18^{\prime}-22^{\circ} 54^{\prime} \mathrm{S}\right.$ and $\left.33^{\circ} 10^{\prime}-34^{\circ} 39^{\prime} \mathrm{E}\right)$ districts of Mozambique $\left(10^{\circ} 30^{\prime}-26^{\circ} 52^{\prime} \mathrm{S}\right.$ and $30^{\circ} 15^{\prime}$ $-40^{\circ} 45^{\prime} \mathrm{E}$ ), in southern Africa. The physical and natural conditions of the study areas are shown in Table 1.

\section{Data collection}

Ninety-three trees with DBH varying from 5 to $32 \mathrm{~cm}$ (average $=17.6 \mathrm{~cm}$ ) and total height varying from 5 to $16 \mathrm{~m}$ (average $=12.3 \mathrm{~m}$ ) were randomly selected and destructively measured. The trees were distributed across each site and DBH class as shown in Table 2. Felled trees were scaled up to a $2.5 \mathrm{~cm}$ top diameter. The stem was defined as the length of the trunk from the predefined stump height $(20 \mathrm{~cm})$ to the height that corresponded to a stem diameter of $2.5 \mathrm{~cm}$. The trees had stem lengths varying from 4.25 to $14.85 \mathrm{~m}$ (average $=10.78 \mathrm{~m}$ ). Discs of approximately $5 \mathrm{~cm}$ thickness were taken from each tree at eight heights along the stem: breast height, $0,10,30,50,70,90$ and $100 \%$ of stem height.

Diameters over and under bark (DOB and DUB, respectively) were measured on each disc in the northsouth direction (previously marked on the standing tree) using a ruler. The volume of the discs, before and after debarking, was determined using the water displacement method (Brasil et al. 1994). Therefore, it was possible to obtain disc volumes over and under bark. Bark volume was determined as the difference between disc volume over and under bark.

Wood discs and associated bark were oven dried at $105^{\circ} \mathrm{C}$ to constant mass. Wood and bark density were obtained by dividing the oven dry-mass of the disc and 
TABLE 1: Description of the study sites

\begin{tabular}{|c|c|c|c|c|}
\hline \multirow{2}{*}{ District } & \multicolumn{4}{|c|}{ Description } \\
\hline & Climate and hydrology & Relief, topography and elevation & $\mathbf{N}\left(\mathbf{h a}^{-1}\right)$ & $\mathbf{G}\left(\mathrm{m}^{2} \mathbf{h a}^{-1}\right)$ \\
\hline Mandlakaze & $\begin{array}{l}\text { Climate: dry and humid tropical; AHM: } 34 \text {; } \\
\text { AI: } 0.7 \text {; Hydrology: } 63 \text { lakes and } 2 \text { rivers. }\end{array}$ & $\begin{array}{l}\text { Relief and topography: flat. } \\
\text { Elevation: } 50 \text { to } 200 \mathrm{~m} \text { a.s.l. }\end{array}$ & 732 & 17 \\
\hline Funhalouro & $\begin{array}{l}\text { Climate: dry semi-arid; AHM: } 52 ; \mathrm{AI} \text { : } \\
0.4 \text {; Hydrology: not crossed by any river, } \\
\text { occurrence of meteorological droughts. }\end{array}$ & $\begin{array}{l}\text { Relief and topography: flat. } \\
\text { Elevation: } 100 \text { to } 200 \mathrm{~m} \text { a.s.l. }\end{array}$ & 1617 & 26 \\
\hline Mabote & $\begin{array}{l}\text { Climate: dry tropical; AHM: } 57 \text {; AI: } 0.4 ; \\
\text { Hydrology: not crossed by any river, } \\
\text { occurrence of meteorological droughts. }\end{array}$ & $\begin{array}{l}\text { Relief and topography: flat. } \\
\text { Elevation: } 100 \text { to } 200 \mathrm{~m} \text { a.s.l. }\end{array}$ & 1333 & 21 \\
\hline
\end{tabular}

Where $\mathrm{N}$ is number of Lebombo ironwood trees per hectare ( $\mathrm{DBH} \geq 5 \mathrm{~cm})$, G respective basal area, AHM annual heat moisture index, and $\mathrm{AI}$ aridity index. Source: MAE (2005a, 2005b, 2014), Magalhães (2017b).

the bark by the relevant volume (Magalhães \& Seifert 2015). Bark volume proportion (hereafter referred simply as bark volume) was calculated as the percentage of bark volume relative to total disc volume. Similarly, bark mass proportion (hereafter referred simply as bark mass) was calculated as the percentage of bark oven dry-mass relative to the total disc oven dry-mass. Double bark thickness was determined as the difference between DOB and DUB. In total, 744 measurements of wood and bark density, bark volume and mass and double bark thickness were taken along the stems of the 93 sample trees.

Whole-stem wood and bark properties under study were calculated using data on the respective properties obtained at eight heights up the stem (i.e. breast height, $0,10,30,50,70,90$ and $100 \%$ of stem height). Table 3 shows the correlation matrix between the wood and bark properties.

\section{Data analysis}

Three-way nested multivariate analysis of variance (nested MANOVA) was performed to test the significance of site, diameter class, and height level on the wood and bark properties under study. Commonality analysis was carried out to quantify how much of the variation in wood and bark properties was explained by the variance of all the predictors (site, DBH class, height level) and quantify the variance that was unique to each

TABLE 2: Number of harvested trees per site and diameter class

\begin{tabular}{ccccc}
\hline $\begin{array}{c}\text { Mid } \\
\text { DBH } \\
\text { (cm) }\end{array}$ & Mandlakaze & Funhalouro & Mabote & Total \\
\hline 7.5 & 3 & 6 & 9 & 18 \\
12.5 & 3 & 7 & 8 & 18 \\
17.5 & 4 & 6 & 8 & 18 \\
22.5 & 4 & 5 & 8 & 17 \\
$27.5+$ & 6 & 7 & 9 & 22 \\
Total & 20 & 31 & 42 & 93 \\
\hline
\end{tabular}

predictor and the variance that was common to groups of predictors. One-way nested analyses of variance (nested ANOVA), with Tukey's HSD test, were carried out to verify the difference between whole-stem wood and bark properties and the relevant properties at different height levels within the stem.

All statistical analyses and tests were carried out using R software (R Core Team 2019). One-way ANOVA and three-way MANOVA were run using the functions "aov" and "manova", respectively. Interactions plots were built using "ggplot2" package (Wickham et al. 2018). Commonality analyses were performed using "yhat" package (Nimon et al. 2015). All tests were performed at significance level of $\alpha=0.05$.

\section{Results}

\section{Basic wood density}

The average $( \pm$ SE) whole-stem wood density for all sites (whole population) was estimated at $786( \pm 2.2) \mathrm{kg} \mathrm{m}^{-3}$, ranging among sites from $783( \pm 3.0)$ to $790( \pm 4.5) \mathrm{kg}$ $\mathrm{m}^{-3}$. Whole-disc wood density ranged from $729( \pm 6.7)$ to 872 ( \pm 4.2 ) $\mathrm{kg} \mathrm{m}^{-3}$ within a tree (longitudinally) and from $760( \pm 6.6)$ to $807( \pm 4.2) \mathrm{kg} \mathrm{m}^{-3}$ among diameter classes.

Whole-disc wood density decreased considerably with height. It increased slightly with diameter class from mid DBH of 7.5 to $12.5 \mathrm{~cm}$ and then it remained constant to the mid DBH of $22.5 \mathrm{~cm}$ from where it increased slightly again (Figure 1). However, it did not show a significant variation with site. For Mandlakaze and Mabote districts, the whole-stem wood density was only found to be different to the wood density at the base and top of the stem (relative heights of 0.0 and 1.0), but no significant differences were found between wholestem density and the densities of other height levels. For Funhalouro district and for the whole population, significant differences were only observed with the densities at relative heights of 0.0, 0.9 and 1.0.

Diameter class and height level were found to be significant sources of variation of wood density $(\mathrm{P}<$ 0.0001; Table 4). Site was not a significant source of variation of wood density $(\mathrm{P}=0.15)$. The interactions 
TABLE 3: Person's correlation matrix for wood and bark properties

\begin{tabular}{|c|c|c|c|c|c|}
\hline & Wood density & Bark density & Bark volume & Bark content & Bark thickness \\
\hline Wood density & 1.0000 & 0.2577 & -0.4069 & -0.4846 & 0.3236 \\
\hline Bark density & & 1.0000 & -0.3064 & -0.2339 & 0.4345 \\
\hline Bark volume & & & 1.0000 & 0.8136 & -0.2470 \\
\hline Bark content & & & & 1.0000 & -0.4441 \\
\hline Bark thickness & & & & & 1.0000 \\
\hline
\end{tabular}

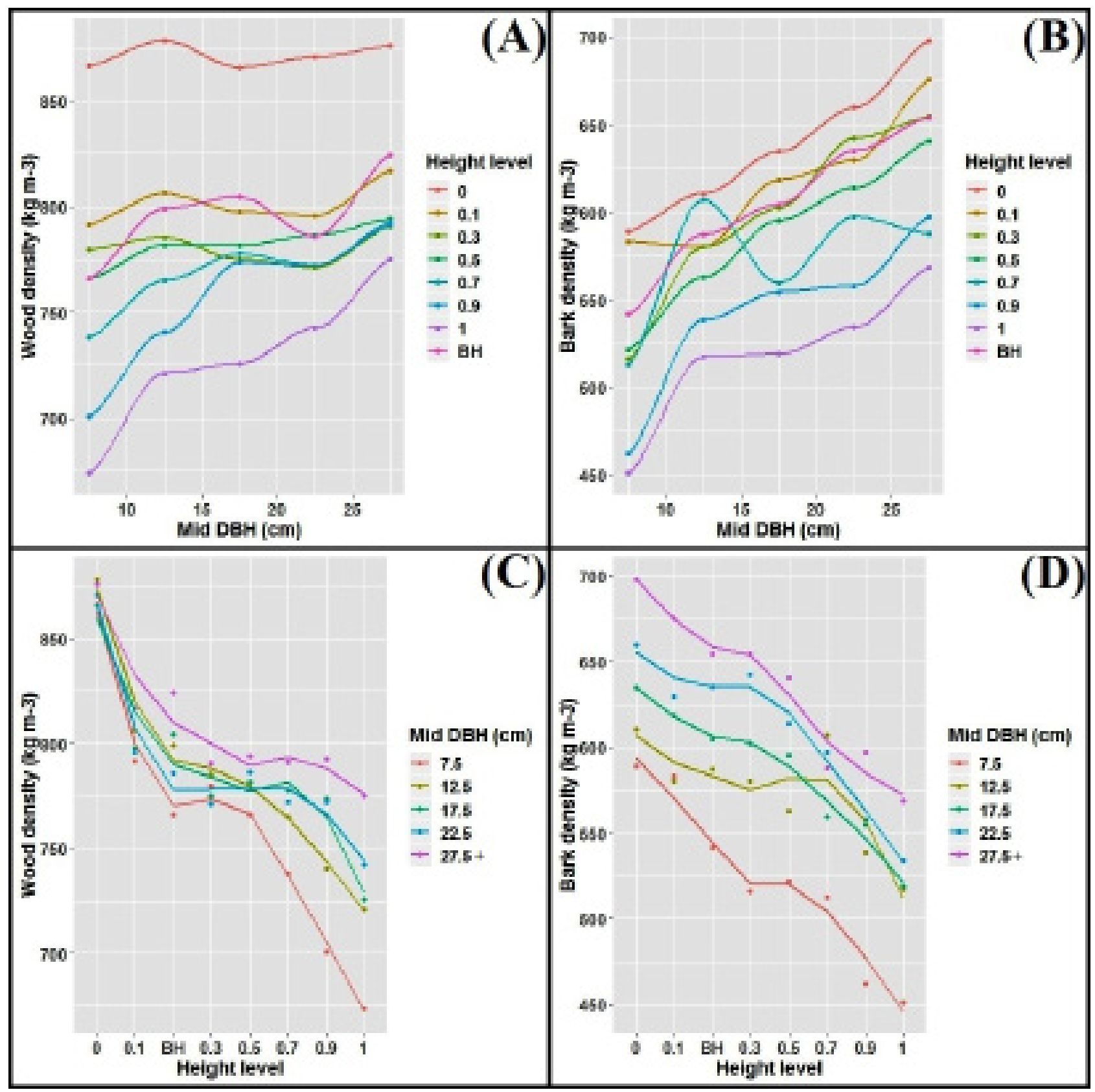

FIGURE 1: Pattern of variation of wood and bark density with DBH class (A and B) and height level (C and D). 
TABLE 4: Multivariate analysis of variance and omega-squared $\left(\omega^{2}\right)$ for wood and bark properties

\begin{tabular}{|c|c|c|c|c|c|c|c|c|c|c|c|}
\hline \multirow{2}{*}{ Factors and interactions } & \multirow{2}{*}{ df } & \multicolumn{2}{|c|}{ Wood density } & \multicolumn{2}{|c|}{ Bark density } & \multicolumn{2}{|c|}{ Bark volume } & \multicolumn{2}{|c|}{ Bark mass } & \multicolumn{2}{|c|}{$\begin{array}{c}\text { Bark } \\
\text { thickness }\end{array}$} \\
\hline & & P-value & $\begin{array}{c}\omega^{2} \\
(\%)\end{array}$ & P-value & $\begin{array}{c}\omega^{2} \\
(\%)\end{array}$ & P-value & $\begin{array}{c}\omega^{2} \\
(\%)\end{array}$ & P-value & $\begin{array}{c}\omega^{2} \\
(\%)\end{array}$ & P-value & $\begin{array}{c}\omega^{2} \\
(\%)\end{array}$ \\
\hline Site & 2 & 0.1513 & 0.1 & 0.0085 & 0.7 & 0.0001 & 0.6 & 0.4742 & 0.0 & 0.0000 & 4.4 \\
\hline DBH class & 4 & 0.0000 & 6.2 & 0.0000 & 14.2 & 0.0000 & 2.4 & 0.0000 & 2.4 & 0.0000 & 27.2 \\
\hline Height level & 7 & 0.0000 & 39.9 & 0.0000 & 12.4 & 0.0000 & 65.0 & 0.0000 & 70.0 & 0.0000 & 21.2 \\
\hline Site $\times$ DBH class & 8 & 0.0000 & 1.8 & 0.0014 & 1.7 & 0.2129 & 0.1 & 0.0000 & 1.2 & 0.0150 & 0.8 \\
\hline Site $\times$ Height level & 14 & 0.0010 & 1.5 & 0.9429 & 0.0 & 0.0473 & 0.4 & 0.0044 & 0.4 & 0.2194 & 0.4 \\
\hline DBH class $\times$ Height level & 28 & 0.0005 & 2.2 & 0.8773 & 0.0 & 0.0000 & 2.3 & 0.0000 & 7.2 & 0.0015 & 2.1 \\
\hline Site $\times$ DBH class $\times$ Height level & 56 & 0.9505 & 0.0 & 0.3753 & 0.3 & 0.9948 & 0.0 & 0.0014 & 0.9 & 0.8667 & 0.0 \\
\hline Residuals & 624 & & & & & & & & & & \\
\hline
\end{tabular}

Where df are degrees of freedom

between site and DBH class, site and height level, DBH class and height level had statistically significant effects on wood density $(\mathrm{P}<0.0001)$. However, the interaction between site, DBH class and height level had no significant effect $(\mathrm{P}=0.95$; Table 4$)$.

From the commonality analysis (Table 5) it was found that the unique effects and the common effects together explained $47.13 \%$ (sum of commonality coefficients) of the variation of wood density: i.e., the regression effect explained $47.13 \%$ of the variation of wood density. Most of that regression effect (85.78\%) was explained by variance that was unique to height level. DBH class and site accounted for 13.68 and $0.44 \%$ of the regression effect, respectively. Together, the three independent variables uniquely accounted for $99.90 \%$ of the regression effect. The remaining $0.1 \%$ was due to the common effect of site and DBH class.

\section{Basic bark density}

Site, diameter class, and height level were found to be significant sources of variation in bark density $(\mathrm{P}<$ 0.0001; Table 4). Only the interactions between site and DBH class had a significant effect on bark density $(\mathrm{P}<$ $0.0001)$. Higher values of bark density were observed in Funhalouro district (with an average $( \pm$ SE) whole-stem density of $\left.597( \pm 4.6) \mathrm{kg} \mathrm{m}^{-3}\right)$ and the lower ones in Mandlakaze district (with a whole-stem density of 574 $( \pm 9.1) \mathrm{kg} \mathrm{m}^{-3}$ ). Mabote district had intermediate bark density values.

Whole-stem bark density increased significantly with increasing diameter class, from an average $( \pm S E)$ value of $522( \pm 8.2) \mathrm{kg} \mathrm{m}^{-3}$ for the smallest diameter class to 634 $( \pm 8.5) \mathrm{kg} \mathrm{m}^{-3}$ for the largest diameter class (Figure 1). Bark density decreased considerably with relative height up the stem, with an overall decrease of approximately $20 \%$ from the bottom to the top of the stem.

TABLE 5: Commonality analyses for wood and bark density

\begin{tabular}{lrrrr}
\hline \multirow{2}{*}{ Factors and interactions } & \multicolumn{2}{c}{ Wood density } & \multicolumn{2}{c}{ Bark density } \\
\cline { 2 - 5 } & $\begin{array}{r}\text { Commonality } \\
\text { coefficient }\end{array}$ & $\begin{array}{r}\text { \% of total } \\
\text { variance }\end{array}$ & $\begin{array}{r}\text { Commonality } \\
\text { coefficient }\end{array}$ & $\begin{array}{r}\text { \% of total } \\
\text { variance }\end{array}$ \\
\hline Site & 0.0021 & 0.44 & 0.0157 & 5.50 \\
DBH class & 0.0645 & 13.68 & 0.1463 & 51.11 \\
Height level & 0.4043 & 85.78 & 0.1306 & 45.63 \\
Site $\times$ DBH class & 0.0005 & 0.10 & -0.0064 & -2.24 \\
Site $\times$ Height level & 0.0000 & 0.00 & 0.0000 & 0.00 \\
DBH class $\times$ Height level & 0.0000 & 0.00 & 0.0000 & 0.00 \\
Site $\times$ DBH class $\times$ Height level & 0.0000 & 0.00 & 0.0000 & 0.00 \\
Total & 0.4713 & 100.00 & 0.2862 & 100.00 \\
\hline
\end{tabular}


The regression effect explained $28.62 \%$ of the variation of bark density (Table 5). Of that regression effect, $51.11 \%$ was explained by the variance that was unique to DBH class and $45.63 \%$ was explained by the variance that was unique to height level (Table 5). The variance unique to the site explained only $5.50 \%$ of the total regression effect. The interaction of site and height level had a negative effect on bark density, meaning that the predictor variables site and height level affected each other in the opposite direction. This suppression accounted for $2.24 \%$ of the regression effect. Overall, the first-order effects (variance unique to the independent variables), second-order effects (variance common to pair of predictors), and third-order effects (variance common to all three predictors together) accounted for $102.24,-2.24$, and $0.0 \%$ of the regression effect, respectively, totalling $100 \%$.

It was observed that in Mandlakaze and Mabote districts, bark density at different height levels was not significantly different from the whole-stem bark density. For Funhalouro district and for the whole population, the whole-stem bark density was only significantly different from the bark densities at relative heights of 0.0 and 1.0.

\section{Bark volume}

The average $( \pm$ SE) whole-stem bark volume for all sites was $19( \pm 0.4) \%$, ranging from $18( \pm 0.6)$ to $20( \pm 0.7)$ $\%$ among sites. Bark volume proportion ranged from 11 $( \pm 0.4)$ to $33( \pm 0.8) \%$ within-tree, and from $18( \pm 0.9)$ to $21( \pm 0.6) \%$ between DBH classes. Overall, Funhalouro district had the lowest values, followed in an increasing order by Mabote and Mandlakaze. In general, bark volume decreased slightly with DBH class and increased sharply with height level. The patterns of variation in bark volume at relative heights of 0.9 and 1.0 with site and DBH class were opposite to those observed at other height levels (Figure 2).

Site, diameter class, and height level were significant sources of variation of bark volume (Table 4). Although statistically significant, site and DBH class contributed very little to the total variation in bark volume (Tables 4 \& 6). Site and DBH class accounted for only 1.25 and $3.75 \%$ of the total regression effect $(68.64 \%)$. Thus, most of the regression effect was explained by the variance that was unique to height level (95.22\%). The only significant common effect was between site and DBH class which, however, was a suppressor effect. Although the second- and third-order interactions had a statistically significant effect on bark volume (Table 4), none of them contributed to the total regression effect (Table 6).

Whole-stem bark volume was statistically different from the bark volume at different height levels, except at relative height of $0.3,0.5$ and 0.7 for Mandlakaze and Mabote districts and only at relative height of 0.5 for Funhalouro district and the whole population.

\section{Bark mass}

The average ( \pm SE) whole-stem bark mass for all sites was estimated at $19( \pm 0.3) \%$, and it was constant all over the sites. Average bark mass ranged from 10 $( \pm 0.3)$ to $32( \pm 0.6) \%$ within a tree (longitudinally), with the smallest values at the bottom of the stem. It ranged from $17( \pm 0.8)$ to $21( \pm 0.5) \%$ among DBH classes. Overall, bark mass decreased slightly with DBH class and increased sharply with increasing height level (Figure 2). The pattern of variation of bark mass was independent of site ( $\mathrm{P}=0.47)$. However, it was dependent of other factors (DBH class and height level) and all interactions $(\mathrm{P}<0.0001 ;$ Table 4). The regression effect explained $72.72 \%$ of the variation in bark mass, of which $96.56 \%$ was explained uniquely by the variance of the height level. The variance of DBH class ranked next, accounting for $3.39 \%$ of the regression effect. Site effects ranked last, accounting only for $0.05 \%$. None of the common effects accounted for the regression effect.

For Funhalouro and Mabote districts and for the whole population, whole-stem bark mass was significantly different from the bark mass at all height levels, except at a relative height of 0.5 . For Mandlakaze district, wholestem bark mass was only significantly different from bark mass at relative heights of 0.0 and 1.0.

\section{Double bark thickness}

The average whole-stem double bark thickness and the double bark thickness at most height levels increased sharply from Funhalouro to Mabote district. However, from Mabote to Mandlakaze district it either showed a slight increase or decrease or remained constant. Double bark thickness was found to increase sharply and rapidly with increasing DBH class (Figure 3). Average double bark thickness, for all sites and most DBH classes, increased slightly with increasing height level to the breast height or to the relative height of 0.3 , and then it decreased non-linearly and rapidly to the top of the stem, resembling a quadratic parabola function (Figure 3).

The average $( \pm \mathrm{SE})$ whole-stem double bark thickness for all sites was estimated at $9( \pm 0.2) \mathrm{mm}$, ranging between sites from $8( \pm 0.2)$ to $10( \pm 0.4) \mathrm{mm}$. Average double bark thickness also ranged from $4( \pm 0.2)$ to 11 $( \pm 0.5) \mathrm{mm}$ within an individual tree (higher values at the base of the stem) and from $5( \pm 0.2)$ to $12( \pm 0.4) \mathrm{mm}$ among DBH classes.

Site, diameter class, and height level were significant sources of variation of double bark thickness $(\mathrm{P}<0.0001$; Table 4). The interactions of site and DBH class, and DBH class and height level had a statistically significant effect on double bark thickness $(\mathrm{P}<0.02)$.

The regression effect explained $53.45 \%$ of the variation of double bark thickness (Table 6). Of that regression effect, $51.24 \%$ was explained by the variance that was unique to DBH class and $40.27 \%$ was explained by the variance that was unique to height level (Table 6). The variance unique to the site explained 6.22\% of the total regression effect. The only significant common effect was between site and DBH class, accounting for $2.27 \%$ of the regression effect. Double bark thickness at most of the height levels was not significantly different from the whole-stem bark thickness. 


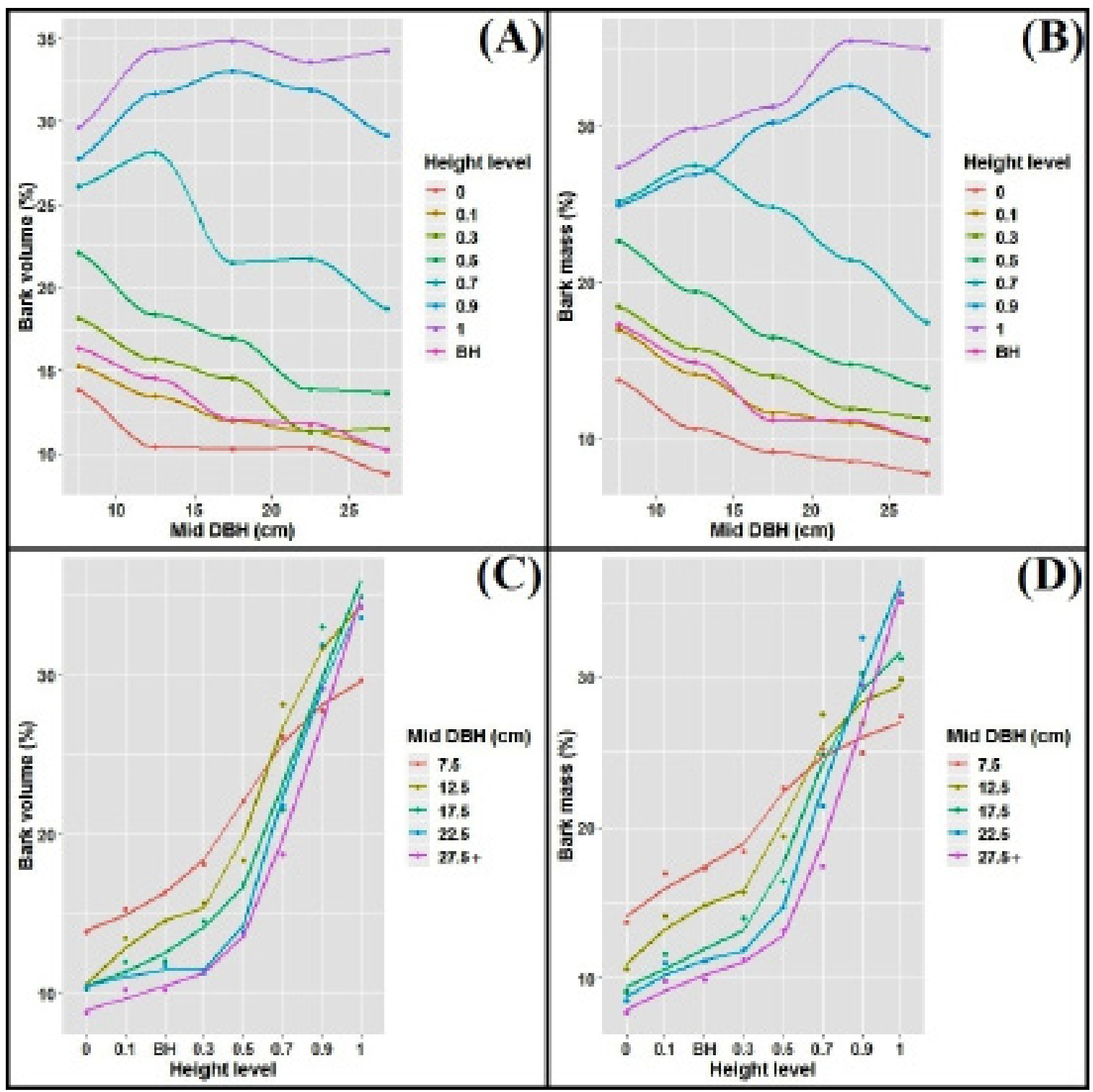

FIGURE 2: Pattern of variation of bark volume and bark mass with DBH class (A and B) and height level (C and D).

TABLE 6: Commonality analyses for bark volume, bark mass and bark thickness

\begin{tabular}{lcccccc}
\hline & \multicolumn{2}{c}{ Bark volume } & \multicolumn{2}{c}{ Bark mass } & \multicolumn{2}{c}{ Bark thickness } \\
\cline { 2 - 7 } Factors and interactions & $\begin{array}{l}\text { Commonality } \\
\text { coefficient }\end{array}$ & $\begin{array}{l}\text { \% of total } \\
\text { variance }\end{array}$ & $\begin{array}{l}\text { Commonality } \\
\text { coefficient }\end{array}$ & $\begin{array}{l}\text { \% of total } \\
\text { variance }\end{array}$ & $\begin{array}{l}\text { Commonality } \\
\text { coefficient }\end{array}$ & $\begin{array}{c}\text { \% of } \\
\text { total } \\
\text { variance }\end{array}$ \\
\hline Site & 0.0086 & 1.25 & 0.0003 & 0.05 & 0.0332 & 6.22 \\
DBH class & 0.0257 & 3.75 & 0.0247 & 3.39 & 0.2739 & 51.24 \\
Height level & 0.6536 & 95.22 & 0.7022 & 96.56 & 0.2152 & 40.27 \\
Site $\times$ DBH class & -0.0015 & -0.22 & 0.0000 & 0.00 & 0.0121 & 2.27 \\
Site $\times$ Height level & 0.0000 & 0.00 & 0.0000 & 0.00 & 0.0000 & 0.00 \\
DBH class $\times$ Height level & 0.0000 & 0.00 & 0.0000 & 0.00 & 0.0000 & 0.00 \\
Site $\times$ DBH class $\times$ Height level & 0.0000 & 0.00 & 0.0000 & 0.00 & 0.0000 & 0.00 \\
Total & 0.6864 & 100.00 & 0.7272 & 100.00 & 0.5345 & 100.00 \\
\hline
\end{tabular}




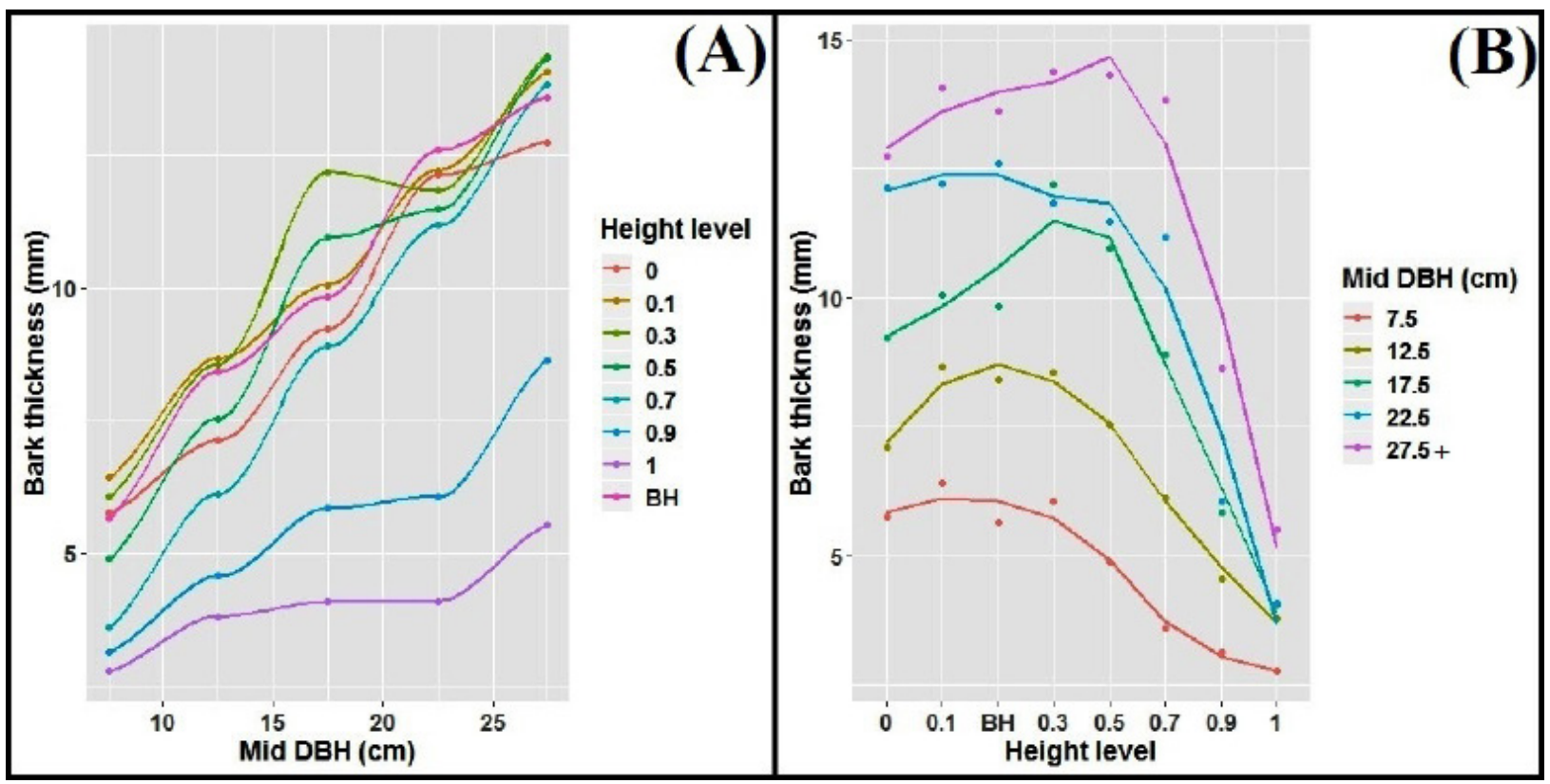

FIGURE 3: Pattern of variation of bark thickness with DBH class (A) and height level (B).

\section{Discussion}

The overall average wood density at breast height found in this study $\left(786 \mathrm{~kg} \mathrm{~m}^{-3}\right.$ ) is higher than that reported by Bunster (2006) and Magalhães (2015) (754 $\mathrm{kg} \mathrm{m}^{-3}$ ). The reason for this difference is because, as opposed to this study, these authors reported wood density over bark. However, calculations based on the wood and bark density and bark volume and mass revealed that the density over bark for this study $\left(749 \mathrm{~kg} \mathrm{~m}^{-3}\right)$ is close to the value reported by Bunster (2006) and Magalhães (2015).

The overall density of bark at breast-height of Lebombo ironwood $\left(606 \mathrm{~kg} \mathrm{~m}^{-3}\right)$ was higher than that of the wood of some Miombo woodland species in Mozambique (Bunster 2006): Pterocarpus angolensis (558 kg m $\mathrm{kg}^{-3}$ ), Khaya nyasica $\left(599 \mathrm{~kg} \mathrm{~m}^{-3}\right)$ Balanites maughamii $\left(584 \mathrm{~kg} \mathrm{~m}^{-3}\right)$, Brachystegia spiciformis (588 $\left.\mathrm{kg} \mathrm{m}^{-3}\right)$.

Overall, wood and bark density decreased with increasing height level of the stem and increased with increasing DBH class. Conversely, bark volume and bark mass increased with increasing height level of the stem and decreased with increasing DBH class. This is supported by the Person's correlation matrix (Table 3), which indicate a positive correlation between wood density and bark density, and a negative one between density (either of the wood or of the bark) with bark proportion (either on volume or on dry-mass basis). These results were consistent with the findings of Nyg and Elfving (2000) and Deng et al. (2014). Contrary to the findings of this study, Deng et al. (2014) found statistical differences between whole-stem wood density and the density at different height levels up the stem.

As in this study, no significant site effects on wood density were found by Nyg and Elfving (2000) for 57 African tree species. Knapic et al. (2008) and Miranda et al. (2001) also found similar results. Wood density has been reported to be positively correlated to droughtprone areas or areas with drier climatic conditions (Ibanez et al. 2017; Nabais et al. 2018).Although Funhalouro and Mabote districts are approximately twice as dry as Mandlakaze district, as judged by annual heat moisture index (AHM) and aridity index (AI) (Table 1 ), wood density did not differ among districts (sites) (Table 4). This indicates that climatic conditions were not a source of variation of wood density of Lebombo ironwood or that wood density of this species does not adapt in response to climatic variations.

A decrease in wood density with increasing stem height has been reported by various authors (e.g. Machado et al. 2014, Kimberley et al. 2015). Machado et al. (2014) suggested that the highest values of wood density at stem base might be the result of the root system and the lowest values at the top of stem are the result of youngest layers of the wood. It was presumed in this study that the lowest wood density for smallest trees in DBH (trees at DBH class of $7.5 \mathrm{~cm}$ ) is also a result of younger layers of wood in these trees.

The increase of wood density with increasing DBH class is a result of the age of the trees: holding all other factors constant, larger trees are often older than smaller ones. Beets et al. (2012) reported that wood density at a given height up the stem increased with increasing age.

Because density measurements were made on unextracted samples (i.e. without the resins and other chemical constituents of heartwood removed), some of the trends in density may be an artefact of the heartwood content in a disc. Heartwood is reported to decrease with height (Miranda et al. 2015) and to be absent above $7.0 \mathrm{~m}$ in height up the stem (Pérez et al. 2004). The decreased heartwood proportion with increasing 
height and its absence in the upper portion of the stem may contribute to the trend of decreasing wood density with increasing height. This, in turn, may contribute to the increased proportions of bark volume and mass with increasing height. Heartwood is also known to increase with increasing stem diameter (Tewari \& Mariswamy 2013), which possibly also explains the increased wood density with DBH class observed in this study. Therefore, the observed trend of decreased bark volume and mass with increasing DBH class may also be an artefact of increasing heartwood proportion with diameter.

Bark volume and bark mass estimated in this study are useful for estimating wood volume under bark and stem wood biomass. In Mozambique, members of the local communities use Lebombo ironwood trees for construction, as stakes or poles (Magalhães 2017a; Magalhães 2017b). The stakes and poles are debarked in the forest and the bark left in the forest floor and decompose (Magalhães 2017a). Thus, bark mass can be used to estimate the carbon dioxide that is released and the nutrients that are reclaimed by the site.

Bark volume values reported in this study 11 $33 \%$ ) are in line with those reported by Murphy and Cown (2015) for Pinus radiata (3.4 - 31.3\%) and Pérez Cordero and Kanninen (2003) for Tectona grandis (14 $37 \%$ ). However, in this study, bark volume was found to increase sharply with increasing height level as opposite to the findings by Murphy and Cown (2015) and Antony et al. (2015). Similarly to the findings by various studies (e.g. Pérez Cordero and Kanninen 2003, Pérez et al. 2004, Antony et al. 2015, Murphy \& Cown 2015), here bark volume percentage was higher for smaller diameter trees.

The average bark mass reported in this study (19\%) was larger than that reported by Eberhardt et al. (2017) for Pinus taeda (12.5\%) and Pinus elliottii (17\%). The pattern of variation of bark mass and bark thickness were in agreement with that reported by Quilhó and Pereira (2001) and Cellini et al. (2012): bark mass was site independent and increased with relative height up the stem. Bark thickness, on the other hand, increased with DBH and decreased with relative height up the stem. Bark thickness is known to increase with tree age (Cellini et al. 2012; Williams et al. 2007) and, consequently, with tree diameter (Chowdhury et al. 2013; Nefabas and Gambiza 2007; Sonmez et al. 2007; Williams et al. 2007; Zeibig-Kichas et al. 2016). As in this study, Williams et al. (2007) found that the bark was thicker at lower portion of the stem for six South African tree species.

The average bark thickness of Lebombo ironwood ( $9 \mathrm{~mm}$, range: $4-12 \mathrm{~mm}$ ) was two times higher than that reported by Paine et al. (2010) for tropical rainforest trees in French Guinea, Western Africa $4.5 \mathrm{~mm}$, range: $0.5-29 \mathrm{~mm}$ ), however with a narrower range. In semi-arid savannahs of Zimbabwe, bark thickness was reported to vary from 4.3 to $15.2 \mathrm{~mm}$ (Nefabas \& Gambiza 2007). Paine et al. (2010) found that bark thickness was strongly positively correlated with DBH, consistent with the finding of this study, where DBH explained the majority of the regression effect. Sonmez et al. (2007) also found that most of the regression effect on bark thickness was accounted by variation in DBH class.

Site was a significant source of variation of bark thickness. Funhalouro and Mabote districts share similarities with regard to site quality (precipitation, soils, hydrology, metrological droughts) but both differ in comparison to Mandlakaze district (Magalhães 2017b). Nonetheless, although with marked differences in soil and climatic conditions, the average bark thickness of trees from Mandlakaze did not differ from those sampled at Mabote. On the other hand, although with no apparent differences in soil and climatic conditions, the bark of trees from Mabote district was, on average, 25\% thicker than that of trees from Funhalouro district. This suggests that soil and climatic and/or environmental conditions were not the sources of variation of bark thickness between sites. A similar observation was made by Rosell (2016) who found that environmental conditions were less important driver of bark thickness.

In this study, it was found that DBH class explained most of the regression effect of bark thickness (51.24\%), followed by height level (40.27\%). Site explained the minority of the regression effect (6.22\%). These findings are consistent with the results by Rosell (2016) who, based on 640 tree species from 153 angiosperm families, found that stem size was the main source of variation of bark thickness, with environmental conditions being less important.

Bark thickness is reported to be positively correlated with fire-prone habitats (Hoffmann and Solbrig 2003; Nefabas and Gambiza 2007; Nieuwstadt and Sheil 2005; Uhl and Kauffman 1990). Compared with Mandlakaze, Mabote and Funhalouro are more prone to forest fires due to low precipitation, intensive metrological draughts and intensive slash and burn agriculture. However, the differences in bark thickness are more marked between the fire-prone habitats (Mabote and Funhalouro) than otherwise (e.g. Mabote and Mandlakaze), suggesting that bark thickness was uncorrelated with tree association with fire-prone habitats. This is in agreement with the findings by Paine et al. (2010). In addition, Lebombo ironwood trees are known to be intolerant to fires. They die after being burnt and do not resprout (regrow) (Magalhães 2017a). This is supported by Nefabas and Gambiza (2007) who stated that "although bark thickness contributes to fire tolerance of woody species, it can be misleading to rank species for fire tolerance based on a single variable such as bark thickness". Rosell (2016) found that stem diameter was 25 times more important than fire tolerance in explaining variations in bark thickness.

Wood density over and under bark, bark thickness and therefore bark proportions are often obtained at breast height by extracting wood cores (Chowdhury et al. 2013; Francis 1994; Hietz et al. 2013; Williamson \& Wiemann 2010). This study proved that the abovementioned whole-stem properties can be represented by the equivalent breast height properties, as no significant differences were observed between them. 


\section{Conclusions}

Overall, the patterns of variation of all wood and bark properties of Lebombo ironwood investigated in this study were found to be highly dependent on vertical position within the stem and tree diameter class. Vertical position along the stem uniquely accounted for most of the regression effects for wood density, bark volume and bark mass. Tree diameter class accounted uniquely for most of the regression effect for bark density and bark thickness. Site differences did not account for a significant proportion of the variation in the wood and bark properties investigated in this study. Overall, whole-stem average properties did not differ from the value measured at breast height.

\section{Competing interests}

The author declares that he has no competing interests.

\section{Acknowledgements}

Thanks are addressed to the field team and to the anonymous reviewers. Thanks are extended to Professor Ernesto Uetimane Jr. (Mr Chuck) for sharing the micrographs of Lebombo ironwood and for all his advice.

\section{Abbreviations}

DBH: Diameter at breast height; AHM: annual heat moisture index; AI: aridity index.

\section{Funding}

This work was supported by the Swedish International Development Cooperation Agency (SIDA).

\section{References}

Ali, A.C., Uetimane, E., Lhate, I.A., \& Terziev, N. (2008). Anatomical characteristics, properties and use of traditionally used and lesser-known wood species from Mozambique: a literature review. Wood Sci ence Technology, 453-472. https://doi. org/10.1007/s00226-008-0186-5

Antony, F., Schimleck, L.R., Daniels, R.F., Clark, A., Borders, B.E., Kane, M.B., \& Burkhart, H.E. (2015). Whole-tree bark and wood properties of loblolly pine from intensively managed plantations. Forest Science, 61(1), 55-66. https://doi.org/10.5849/ forsci.12-030

Auty, D., Achim, A., Macdonald, E., Cameron, A.D., \& Gardiner, B.A. (2014). Models for predicting wood density variation in Scots pine. Forestry, 87(3), 449458. https://doi.org/10.1093/forestry/cpu005

Bastin, J.F., Fayolle, A., Tarelkin, Y., Van Den Bulcke, J., De Haulleville, T., Mortier, F., Beeckman H, Van Acker J, Serckx A, Bogaert J, De Cannière C. (2015). Wood specific gravity variations and biomass of central African tree species: The simple choice of the outer wood. PLoS ONE, 10(11), e0142146. https://doi. org/10.1371/journal.pone.0142146

Beets, P.N., Kimberley, M.O., Oliver, G.R., Pearce, S.H., Graham, J.D., \& Brandon, A. (2012). Allometric equations for estimating carbon stocks in natural forest in New Zealand. Forests, 3(3), 818-839. https://doi.org/10.3390/f3030818

Brasil, M.A.M., Veiga, R.A. de A., \& Timoni, J.L. (1994). Erros na determinação da densidade basica da madeira. CERNE, 1(1), 55-57.

Bunster, J. (2006). Commercial timbers of Mozambique: Technological catalogue. Maputo: Trafores Lda.

Cardoso, G.A. (1963). Madeiras de Moçambique: Androstachys johnsonii. Maputo: Serviços de Agricultura e Serviços de Veterinária.

Cellini, J.M., Galarza, M., Burns, S.L., Martínez Pastur, G.J., \& Lencinas, M.V. (2012). Equations of bark thickness and volume profiles at different heights with easymeasurement variables. Forest Systems, 21(1), 2330. https://doi.org/10.5424/fs/2112211-01963

Chowdhury, M.Q., Khan, M.R., \& Mehedi, M.A.H. (2013). Wood density variation in four plantation species growing in Bangladesh. Journal of the Indian Academy of Wood Science, 10(1), 32-38. https:// doi.org/10.1007/s13196-013-0090-y

Deng, X., Zhang, L., Lei, P., Xiang, W., \& Yan, W. (2014). Variations of wood basic density with tree age and social classes in the axial direction within Pinus massoniana stems in Southern China. Annals of Forest Science, 71(4), 505-516. https://doi. org/10.1007/s13595-013-0356-y

Eberhardt, T.L., Dahlen, J., \& Schimleck, L. (2017). Species comparison of the physical properties of loblolly and slash pine wood and bark. Canadian Journal of Forest Research, 47(11), 1495-1505. https://doi. org/10.1139/cjfr-2017-0091

Francis, J.K. (1994). Simple and inexpensive method for extracting wood density samples from tropical hardwoods. Tree Planters Notes, 45(1), 10-12.

Hernández, M.A., \& Genes, P.Y. (2016). Wood density at breast height as estimate of the whole tree density in Grevillea robusta. Australian Forestry, 79(3), 168-170. https://doi.org/10.1080/00049158.201 $\underline{6.1164578}$

Hietz, P., Valencia, R., \& Joseph Wright, S. (2013). Strong radial variation in wood density follows a uniform pattern in two neotropical rain forests. Functional Ecology, 27(3), 684-692. https://doi. org/10.1111/1365-2435.12085

Hoffmann, W.A., \& Solbrig, O.T. (2003). The role of topkill in the differential response of savanna woody species to fire. Forest Ecology and Management, 180(1-3), 273-286. https://doi.org/10.1016/ S0378-1127(02)00566-2 
Ibanez, T., Chave, J., Barrabé, L., Elodie, B., Boutreux, T., Trueba, S., Vandrot, H. \& Birnbaum, P. (2017). Community variation in wood density along a bioclimatic gradient on a hyper-diverse tropical island. Journal of Vegetation Science, 28(1), 19-33. https://doi.org/10.1111/jvs.12456

Kimberley, M.O., Cown, D.J., McKinley, R.B., Moore, J.R., \& Dowling, L.J. (2015). Modelling variation in wood density within and among trees in stands of New Zealand-grown radiata pine. New Zealand Journal of Forestry Science, 45: 22. https://doi. org/10.1186/s40490-015-0053-8

Knapic, S., Louzada, J.L., Leal, S., \& Pereira, H. (2008). Within-tree and between-tree variation of wood density components in cork oak trees in two sites in Portugal. Forestry, 81(4), 465-473. https://doi. org/10.1093/forestry/cpn012

Machado, J.S., Louzada, J.L., Santos, A. J.A., Nunes, L., Anjos, O., Rodrigues, J., Simões, R.M.S. \& Pereira, H. (2014). Variation of wood density and mechanical properties of blackwood (Acacia melanoxylon R. Br.). Materials and Design, 56, 975-980. https:// doi.org/10.1016/j.matdes.2013.12.016

MAE. (2005a). Perfil do distrito de Funhalouro: Província de Inhamabane. Maputo: Ministério de Admnistração Estatal. http://www.govnet.gov.mz/

MAE. (2005b). Perfil do distrito de Mandlakaze: Província de Gaza. Maputo: Ministério de Admnistração Estatal. http://www.govnet.gov.mz/

MAE. (2014). Perfil do Distrito de Mabote: Província de Inhambane. Maputo: Ministério de Admnistração Estatal. http://www.govnet.gov.mz/

Magalhães, T.M. (2017). Carbon stocks in necromass and soil pools of a Mozambican tropical dry forest under different disturbance regimes. Biomass and Bioenergy, 105. https://doi.org/10.1016/j. biombioe.2017.07.023

Magalhães, T.M., \& Seifert, T. (2015). Tree component biomass expansion factors and root-to-shoot ratio of Lebombo ironwood: Measurement uncertainty. Carbon Balance and Management, 10(1). https:// doi.org/10.1186/s13021-015-0019-4

Magalhães, T.M. (2015). Live above- and belowground biomass of a Mozambican evergreen forest: a comparison of estimates based on regression equations and biomass expansion factors. Forest Ecosystems, 2(1), 28. https://doi.org/10.1186/ s40663-015-0053-4

Magalhães, T.M. (2017). Site-specific height-diameter and stem volume equations for Lebombo-ironwood. Annals of Forest Research, 60(2), 297-312. https:// doi.org/10.15287/afr.2017.838

Miranda, I., Almeida, M.H., \& Pereira, H. (2001). Provenance and site variation of wood density in Eucalyptus globulus Labill. at harvest age and its relation to a non-destructive early assessment. Forest Ecology and Management, 149(1-3), 235-240. https://doi.org/10.1016/S03781127(00)00560-0

Miranda, I., Gominho, J., \& Pereira, H. (2015). Heartwood, sapwood and bark variation in coppiced Eucalyptus globulus trees in 2 nd rotation and comparison with the Single-Stem 1st rotation. Silva Fennica, 49(1), 1-13. https://doi.org/10.14214/sf.1141

Molotja, G.M., Ligavha-mbelengwa, M.H., \& Bhat, R.B. (2011). Antifungal activity of root, bark, leaf and soil extracts of Androstachys johnsonii Prain. African Journal of Biotechnology, 10(30), 57255727. https://doi.org/10.5897/AJB10.2212

Murphy, G., \& Cown, D. (2015). Within-tree, betweentree, and geospatial variation in estimated Pinus radiata bark volume and weight in New Zealand. New Zealand Journal of Forestry Science, 45: 18. https://doi.org/10.1186/s40490-015-0048-5

Nabais, C., Hansen, J.K., David-Schwartz, R., Klisz, M., López, R., \& Rozenberg, P. (2018). The effect of climate on wood density: What provenance trials tell us? Forest Ecology and Management, 408, 148-156. https://doi.org/10.1016/j. forec0.2017.10.040

Nefabas, L.L., \& Gambiza, J. (2007). Fire tolerance mechanisms of common woody plant species in a semiarid savanna in south western Zimbabwe. African Journal of Ecology, 45(4), 550-556. https:// doi.org/10.1111/j.1365-2028.2007.00767.x

Nieuwstadt, M.G.L.V.A.N., \& Sheil, D. (2005). Drought, fire and tree survival in Borneo rain forest, East Kalimantan, Indonesia. Journal of Ecology, 93, 191-201. https://doi.org/10.1111/j.13652745.2004.00954.x

Nimon, K., Oswald, F., \& Roberts, J.K. (2015). Yhat: Interpreting regression effects (R Package Version 2.0-0). Vienna: R Foundation for Statistical Computing.

Nyg, R., \& Elfving, B. (2000). Stem basic density and bark proportion of 45 woody species in young savanna coppice in forests in Burkina Faso. Annals of Forest Science, 57(2), 143-153. https://doi.org/10.1051/ forest:2000165

Paine, C.E.T., Stahl, C., Courtois, E.A., Patiño, S., Sarmiento, C., \& Baraloto, C. (2010). Functional explanations for variation in bark thickness in tropical rain forest trees. Functional Ecology, 24(6), 1202-1210. https://doi.org/10.1111/j.13652435.2010.01736.x

Pásztory, Z., Mohácsiné, I.R., Gorbacheva, G., \& Börcsök, Z. (2016). The utilization of tree bark. BioResources, 11(3), 7859-7888. https://doi.org/10.15376/ biores.11.3.Pasztory 
Pérez Cordero, L.D., \& Kanninen, M. (2003). Heartwood, sapwood and bark content, and wood dry density of young and mature teak (Tectona grandis) trees grown in Costa Rica. Silva Fennica, 37(1), 45-54. https://doi.org/10.14214/sf.511

Pérez, D., Kanninen, M., Matamores, F., Fonseca, W., \& Chaves, E. (2004). Heartwood, sapwood and bark contents of Bombacopsis quinata in Costa Rica. Journal of Tropical Forest Science, 16(3), 318-327.

Quilhó, T., \& Pereira, H. (2001). Within and betweentree variation of bark content and wood density of Eucalyptus globulus in commercial plantations. IAWA Journal, 22(3), 255-265. https://doi. org/10.1163/22941932-90000283

R Core Team. (2019). A language and environment for statistical computing. Vienna: $R$ Foundation for Statistical Computing.

Repola, J. (2006). Models for vertical wood density of Scots pine, Norway spruce and birch stems, and their application to determine average wood density. Silva Fennica, 40(4), 673-685. https://doi. org/10.14214/sf.322

Rosell, J.A. (2016). Bark thickness across the angiosperms: More than just fire. New Phytologist, 211(1), 90102. https://doi.org/10.1111/nph.13889

Searle, S.D., \& Owen, J.V. (2005). Variation in basic wood density and percentage heartwood in temperate Australian Acacia species. Australian Forestry, 68(2), 126-136. https://doi.org/10.1080/000491 $\underline{58.2005 .10674956}$

Sonmez, T., Keles, S., \& Tilki, F. (2007). Effect of aspect, tree age and tree diameter on bark thickness of Picea orientalis. Scandinavian Journal of Forest Research, 22(3), 193-197. https://doi. org/10.1080/02827580701314716

Tewari, V.P., \& Mariswamy, K.M. (2013). Heartwood, sapwood and bark content of teak trees grown in Karnataka, India. Journal of Forestry Research, 24(4), 721-725. https://doi.org/10.1007/s11676013-0410-5

Thomas, R.E., \& Bennett, N.D. (2014). Estimating bark thicknesses of common Appalachian hardwoods. In J. W. Groninger, E. J. Holzmueller, C. K. Nielsen, \& D. C. Dey (Eds.), Proceedings of the 19th Central Hardwood Forest Conference (pp. 283-294). Illinois, USA: U.S. Forest Service.

Tian, X., Cown, D., \& McConchie, D. (1995). Modelling of Pinus radiata wood properties. Part 2: Basic density. New Zealand Journal of Forestry Science, 25(2), 214-230.

Uhl, C., \& Kauffman, J.B. (1990). Deforestation, fire susceptibility, and potential tree responses to fire in the eastern Amazon. Ecology, 71(2), 437-449. https://doi.org/10.2307/1940299
Wickham, H., Chang, W., Henry, L., Pedersen, T.L., Takahashi, K., Wilke, C., \& Woo, K. (2018). Ggplot2: Create elegant data visualisations using the grammar of graphics description (R Package Version 3.1.0). Vienna: R Foundation for Statistical Computing.

Williams, V.L., Witkowski, E.T.F., \& Balkwill, K. (2007). Relationship between bark thickness and diameter at breast height for six tree species used medicinally in South Africa. South African Journal of Botany, 73(3), 449-465. $\quad$ https://doi.org/10.1016/j. sajb.2007.04.001

Williamson, G.B., \& Wiemann, M.C. (2010). Measuring wood specific gravity correctly. American Journal of Botany, 97(3), 519-524. https://doi.org/10.3732/ ajb.0900243

Zeibig-Kichas, N.E., Ardis, C.W., Berrill, J.P., \& King, J.P. (2016). Bark thickness equations for mixedconifer forest type in Klamath and Sierra Nevada Mountains of California. International Journal of Forestry Research, 2016, 28-31. https://doi. org/10.1155/2016/1864039 